\title{
Impact of Testing Temperature on the Structure and Catalytic Properties of Au Nanotubes Composites
}

\author{
Anastassiya A. Mashentseva ${ }^{1 *}$, Maxim V. Zdorovets ${ }^{1-3}$, Daryn B. Borgekov ${ }^{1,2}$ \\ ${ }^{1}$ The Institute of Nuclear Physics of the Republic of Kazakhstan, 050032, Ibragimov str., 1, \\ Almaty, Kazakhstan \\ ${ }^{2}$ L.N. Gumilyov Eurasian National University, Satpaev str., 5, 010008 Astana, Kazakhstan \\ ${ }^{3}$ The Ural Federal University named after the first President of Russia B. N. Yeltsin, Mira str. 19, \\ 620002 Yekaterinburg, Russia
}

Received: $23^{\text {rd }}$ January 2018; Revised: $19^{\text {th }}$ March 2018; Accepted: $19^{\text {th }}$ March 2018; Available online: $14^{\text {th }}$ November 2018; Published regularly: December 2018

\begin{abstract}
In the paper, the catalytic activity of composites based on gold nanotubes and ion track membranes was studied using bench reaction of the $p$-nitrophenol (4-NP) reduction in the temperature range of 25$40{ }^{\circ} \mathrm{C}$. The efficiency of the prepared catalysts was estimated on the rate constant of the reaction and by conversion degree of 4-NP to $p$-aminophenol (4-AP). The comprehensive evaluation of the structure was performed by X-ray diffraction and scanning electron microscopy. A decreasing of the composites activity was observed when the reaction were carried out at the temperature over $35{ }^{\circ} \mathrm{C}$, due to an increased average crystallite size from $7.31 \pm 1.07$ to $10.35 \pm 3.7 \mathrm{~nm}$ (after $1^{\text {st }}$ run). In temperature range of $25-35{ }^{\circ} \mathrm{C}$ the efficiency of the composite catalyst was unchanged in 3 runs and decreases by $24-32 \%$ after the $5^{\text {th }}$ run. At the high temperature of $40{ }^{\circ} \mathrm{C}$ after the $5^{\text {th }}$ run the composite become completely catalytically inert. Copyright (C) 2018 BCREC Group. All rights reserved
\end{abstract}

Keywords: Gold Nanotubes; Composite Membrane; Catalysis; Ion Track Membranes

How to Cite: Mashentseva, A.A., Zdorovets, M.V., Borgekov, D.B. (2018). Impact of Testing Temperature on the Structure and Catalytic Properties of Au Nanotubes Composites. Bulletin of Chemical Reaction Engineering \& Catalysis, 13 (3): 405-411 (doi:10.9767/bcrec.13.3.2127.405-411)

Permalink/DOI: https://doi.org/10.9767/bcrec.13.3.2127.405-411

\section{Introduction}

Discovery and further first manufacturing of ion track membranes (ITMs) using accelerated heavy ions in the second half of the last century starts a new stage in the development of classical membrane science. Among many types of the polymeric membranes, ITMs is one of the most promising due well-defined geometry of pores - cylindrical, conical or bottle-shaped et al [1], precise pore diameters $(10 \mathrm{~nm}-5 \mu)$ and narrow pore size distributions [2]. Special at-

\footnotetext{
* Corresponding Author.

E-mail: mashentseva.a@gmail.com (A.A. Mashentseva)

Telp: +7-707-322-43-99, Fax: +7-7172-34-20-78
}

tention is paid to the development of the ion track membranes with defined structures [3,4], physicochemical and transport properties $[5,6]$ as well as to its application in different areas of nanoscience. Currently, such composites based on ITMs and metallic nanostructures has an emerging interest in development of sensors [79] and ion-selective membranes [10,11], new magnetic materials and devices $[12,13]$, in medicine $[14,15]$ and catalysis $[16,17]$.

Also ITMs with embedded metal nanoparticles/NTs possesses a good catalytic ability in reactions being easily passed over the surface as well as through membrane's channels. The main advantages of ITMs-based composites as highly efficient heterogeneous catalysts are: (a) a wide 
range of desired metals/alloys could be easily deposited within the channels of membrane; (b) membrane geometry allow to uniform distribute the catalytically active material over the whole pores surface; (c) possibility to carry out reactions without separation of nanosized catalysts from reaction media after reaction is complete; and (d) polymer template could be easily removed by dissolving in appropriate solvents and the formed nanostructures without morphological changing could be using separately.

Recent literature survey has shown that the catalytic activity of composite membranes could be evaluated with the most well-known bench reaction for evaluation of nanosized catalyst such as 4-NP reduction in presence of sodium borohydride [18,19]. Composite membranes based on ITMs and silver [16,20], gold [21], palladium [22], mixed $\mathrm{Ag} / \mathrm{Au}$ [23], Au/Pt [24], and Ni-Co [25] NTs possesses a good catalytic ability in 4-NP reduction reaction.

Despite the works conducted to explore the potential of ITMs with embedded metallic NSs for the reduction of 4-NP, a comprehensive study of their structure-catalytic activity relationships has not been conducted so far. Therefore, it was our interest to assess the catalytic activity and reusability of composites based on (polyethylene terephthalate) PET ITMs and gold NTS at the different temperatures, as well as estimate changes in structure by XRD and SEM techniques. The present study underlines the great ability of flexible catalyst-coated membranes to accelerate reaction of the $4-\mathrm{NP}$ reduction.

\section{Materials and Methods}

\subsection{Template Preparation and NTs Synthesis}

PET ITMs with nominal thickness $12.0 \mu \mathrm{m}$ were irradiated at the DC-60 heavy ion accelerator in Astana, Kazakhstan with krypton ions (energy: $1.75 \mathrm{MeV} /$ nucleon, fluence: of $1 \times 10^{9}$ ions $/ \mathrm{cm}^{2}$ ). The irradiated film was etched out for $75 \mathrm{sec}$ in $2.2 \mathrm{M} \mathrm{NaOH}$ solution at $85 \pm 1$ ${ }^{\circ} \mathrm{C}$. The pore size did not exceed $100 \pm 5 \mathrm{~nm}$.

Prior to electroless gold deposition, the PET ITMs were exposed to activation and sensitization procedures [26]. Generally, these stages use surface-bound $\mathrm{Sn}(\mathrm{II})$ to reduce $\mathrm{Ag}(\mathrm{I})$, leading to the formation of catalytically active silver NPs on the polymer template. For the polymer's surface sensitization all samples were immersed into a solution of $\mathrm{SnCl}_{2}(25 \mathrm{~g} / \mathrm{L})$ and hydrochloric acid (60 g/L) for $15 \mathrm{~min}$ to and thoroughly rinsed for 15 min under flowing water.
At the next activation stage, the sensitized membrane was immersed for 5 min into $\mathrm{Ag}$ based solution $\left(10 \% \mathrm{AgNO}_{3}, 25 \% \mathrm{NH}_{3}\right.$, and 3 $\% \mathrm{NaOH}$ ) to provide formation of the thin layer of silver nanoparticles [17]. Gold deposition from $\left(\mathrm{Na}_{3}\left[\mathrm{Au}\left(\mathrm{SO}_{3}\right)_{2}\right]\right.$ plating solution was performed for $1 \mathrm{~h}$ at $\mathrm{pH}=12.0$ and temperature 4 ${ }^{\circ} \mathrm{C}$ according to the technique described by Korolkov et al. [27]. To dissolve the PET template for gold NTs characterization, the solution of 1,1,1,3,3,3-hexafluoro-2-propanol and chloroform $\mathrm{CHCl}_{3}$ (1:9 by volume) was used.

\subsection{Characterization}

For Scanning Electron Microscopy (SEM) and Energy Dispersive X-ray Spectroscopy (EDS) a JEOL-7500F instrument was used. For SEM observation, template-free NTs were collected on the carbon tape sputter-coated with gold. X-ray diffraction (XRD) measurements of the "as-prepared" composite membrane samples were obtained on a D8 Advance (Bruker, Germany). X-ray was generated at 40 $\mathrm{mA}$ and $40 \mathrm{kV}$ and the scanning position ranged from $15-90^{\circ} 2(\theta)$. The crystal grain sizes were calculated using Scherrer equation.

\subsection{Catalysis}

The catalytic activity of Au-NTs/PET-ITMs composite membranes was determined in the temperature range of $25-40{ }^{\circ} \mathrm{C}$. Testing sample (a square with side $5 \mathrm{~cm}$ ) was immersed into the stirred reaction mixture of $25 \mathrm{~mL}$ of $3.91 \times 10^{-6} \mathrm{M}$ 4-NP and the $3.91 \times 10^{-3} \mathrm{M} \mathrm{NaBH}_{4}$ aqueous solution. The reaction rate was monitored every 5 minutes using UV-Vis spectrophotometer in the wavelength range 200-600 $\mathrm{nm}$. The residual concentration of $4-\mathrm{NP}$ was determined by using previously prepared calibration curve with formula $y=0.009 x-0.0001$; $\mathrm{R}^{2}=0.9975$. All experiments were repeated five times to prove the recyclability of composite.

\section{Results and Discussion}

Polymeric ITMs are a flexible and universal template material for the synthesis of highly ordered arrays of metallic nanostructures (in the case of matrix removal) as well as nanocomposites (without separation of NSs from the polymer matrix). SEM images of the synthesized Au-NTs/PET-ITMs composite shown in Figure 1. The deposited NTs were grown through the whole PET template and therefore have a length of $12 \mu \mathrm{m}$. The outer nanotube diameter is approximately corresponds to the pore diameter of the template, the inner diam- 
eter and wall thickness were determined to be about $60 \pm 4.2$ and $15.2 \pm 5 \mathrm{~nm}$.

A structural and chemical investigation of the prepared composites was carried out with XRD and EDS techniques. According to XRD measurements (see Figure 2a), XRD pattern of Au-NTs/PET-ITMs composite has a main characteristic peaks at $38.14^{\circ}, 44.42^{\circ}, 64.25^{\circ}$, and $77.74^{\circ}$ related to (111), (200), (220), and (311) planes respectively (JCPDS file N. 040784). The predominant peak at $2(\theta)=38.14^{\circ}$ is indicative of the predominant orientation (111). Broad peaks in the region $15^{\circ}$ to $26^{\circ}$ and $53^{\circ}$ to $57^{\circ}$ are related to the amorphous structure of PET ITMs. The average grain size of the gold NPs on the surface of studied composite was calculated using the Scherrer's formula and presented in the Table 1. EDS (Figure 2a) also confirms that $\mathrm{Au}$ is the main component of the prepared composite. Minor fraction of copper $(4.2 \%)$ as a material of sample holder was also detected.

Starting from Pradhan [28] reduction of 4-NP by sodium borohydride reaction has been used as a benchmark reaction for the evalua- tion of catalytic ability of nanosized catalysts [22]. This reaction could be easily monitored by UV-vis spectroscopy: 4-NP shows a characteristic absorption peak at $400 \mathrm{~nm}$ in water solution from another hand the product, $p$-aminophenol

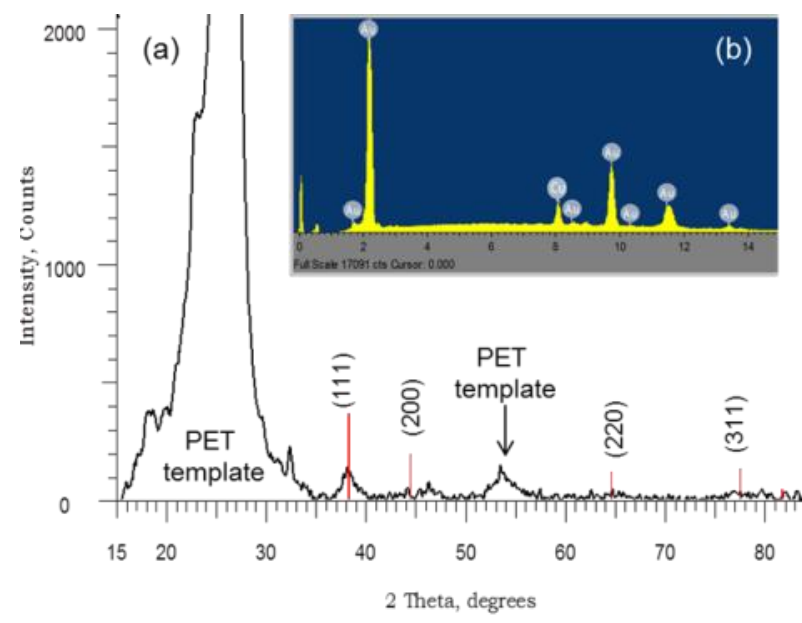

Figure 2. XRD pattern of gold NTs inside the PET template (a) and EDS spectrum of released gold NTs (b)
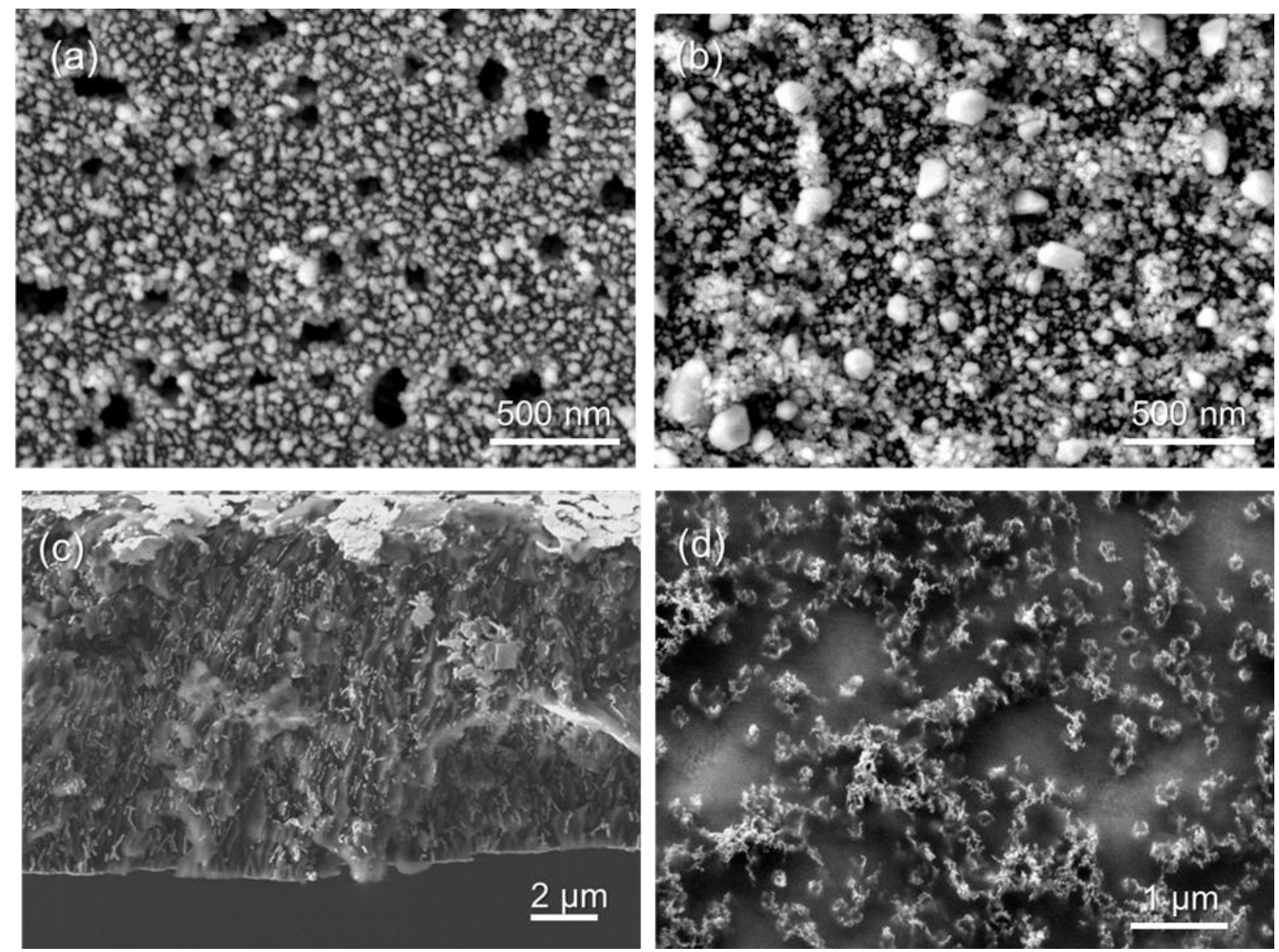

Figure 1. SEM images of Au-NTs/PET-ITMs composite: (a) front side (b) back side, (c) cross-sectional view, and (d) Au NTs after template dissolving 
(4-AP), exhibits a weak absorption peak at around $299 \mathrm{~nm}$ (Figure 3a). The studied reaction has the pseudo-first order in the presence of excess of $\mathrm{NaBH}_{4}$, that allows to study the kinetics of the reaction to change the amount of the starting reagent 4-NP (Figure $3 \mathrm{~b}$ ). The slope of a plot of the natural log of the absorbance at $400 \mathrm{~nm}$ yields $\left(A_{0} / A_{t}\right)$ (Figure 3a) allows to calculate the apparent rate constant $\left(k, \quad \min ^{-1}\right)$. It's should be noted, that without the catalyst the reduction of 4-NP does not proceed, even when increasing the duration of the reaction to 120 hours. The values of $k$ as well as data on conversion degree of the 4-NP are shown in Table 2.

The highest value of constant rate and 4-NP conversion degree was observed while testing at the $35{ }^{\circ} \mathrm{C}$. The decreasing catalytic activity after this point could be attributed to the changes of the Au NTs structure in particular it may be caused by increasing of the gold nanoparticles size on the surface/channels of the composite membrane [23]. Increasing of crystallites size was confirmed by XRD analysis of all samples after the $1^{\text {st }}$ run (Table 2). Thus, the average dimension of the Au nanoparticles on the composites surface was increased from 6.99 up to $10.35 \mathrm{~nm}$.
The effect of the high temperature related to the aggregation of gold nanoparticles on the surface of composite membrane was also observed from SEM images are presented in Figure 4. From another hand, previously was reported that $\mathrm{NaBH}_{4}$ could react to produce hydrogen and boranes and finnaly to decrease the 4-NP reduction degree [29].

One of the most critical problems for development of the non-supported nanosized catalysts is the need for their separation from reaction media and/or regeneration after every run so a small part of NPs could be removed during these manipulations. Composite and supported catalysts compared to their colloidal counterparts are being used more and more to meet the practical catalytic performance requirements in the chemical industry, such as: high activity and selectivity, as well as reusability and good stability [30]. The reusability of studied composites was examined for 5 times and relation between the number of cycles of the reaction and 4-NP conversion degree is illustrated in Figure 5 (data are shown in this graph are presented with allowance for the standard deviation for three measurements).
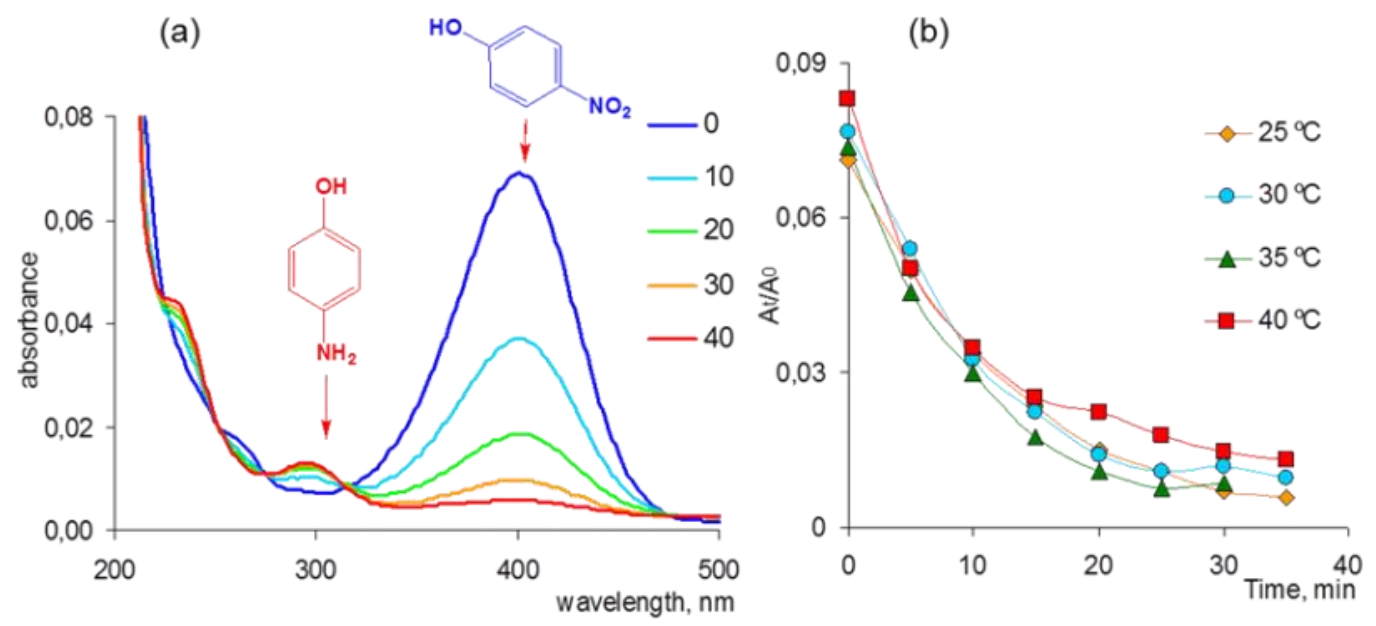

Figure 3. Typical UV-vis spectra of the reduction of 4-NP by sodium borohydride with Au-NTs/PETITMs composite membrane (a) and the decreasing of 4-NP concentration at different temperatures (b)

Table 1. XRD data of the pristine Au-NTs/PET-ITMs composite

\begin{tabular}{cccccc}
\hline $\begin{array}{c}2(\theta), \\
\text { degrees }\end{array}$ & $h k l$ & FWHM & $d, \mathrm{~nm}$ & $\begin{array}{c}\text { Average size, } \\
d, \mathrm{~nm}\end{array}$ & $\begin{array}{c}\text { Cell parameter } \\
a, \AA\end{array}$ \\
\hline 38.14 & 111 & 1.071 & 8.20 & & \\
44.42 & 200 & 1.545 & 5.80 & & \\
64.25 & 220 & 1.335 & 7.34 & $7.31 \pm 1.07$ & $4.080 \pm 0.001$ \\
77.74 & 311 & 1.349 & 7.90 & & \\
\hline
\end{tabular}


In temperature range of $25-35{ }^{\circ} \mathrm{C}$ the efficiency of the composite catalyst was unchanged in 3 runs and decreases by $24-32 \%$ after the $5^{\text {th }}$ run. At the high temperature of $40{ }^{\circ} \mathrm{C}$ after the $5^{\text {th }}$ run the composite convert only $8 \%$ of 4 -NP and become completely catalytically inert.

\section{Conclusion}

In this study, the influence of operating temperature on structure and catalytic ability of membrane composites based on ion track membranes and gold nanotubes was demonstrated. The effect of temperature on the catalytic activity was investigated using benchmark reaction of the 4-nitrophenol to 4-aminophenol reduction in the presence of sodium borohydride in temperature range of 25 $35{ }^{\circ} \mathrm{C}$. The apparent constant rate of studied reaction $k_{a p p}$ initially raised with the increase of temperature below $35^{\circ} \mathrm{C}$, which followed the typical Arrhenius-type dependence on tempera-

Table 2. Structural and kinetic parameters of Au NTs/PET-ITMs composite after $1^{\text {st }}$ run at the different temperatures

\begin{tabular}{cccccccc}
\hline $\mathrm{t},{ }^{\circ} \mathrm{C}$ & $\begin{array}{c}2(\theta), \\
\text { degrees }\end{array}$ & $h k l$ & FWHM & $\begin{array}{c}\text { Average size, } \\
d, \mathrm{~nm}\end{array}$ & $\begin{array}{c}\text { Cell parameter } \\
a, \AA\end{array}$ & $\begin{array}{c}k \times 10^{-2}, \\
\mathrm{~min}^{-1}\end{array}$ & $\begin{array}{c}\text { Conversion 4-NP, } \\
\%\end{array}$ \\
\hline 25 & 38.22 & 111 & 1.045 & $6.99 \pm 1.6$ & 4.0786 & 10.00 & 77.88 \\
& 44.556 & 200 & 1.914 & & & & \\
& 64.54 & 220 & 1.278 & & & & \\
\hline 30 & 77.49 & 311 & 1.481 & & & & \\
& 38.08 & 111 & 1.193 & $7.46 \pm 1.8$ & 4.0754 & 8.97 & \\
& 44.32 & 200 & 1.816 & & & & \\
& 64.89 & 220 & 1.097 & & & & \\
\hline 35 & 77.54 & 311 & 1.237 & & & & \\
& 38.18 & 111 & 0.883 & $9.44 \pm 3.4$ & 4.0829 & & \\
& 44.34 & 200 & 1.587 & & & & \\
& 64.54 & 220 & 1.177 & & & & \\
\hline 40 & 77.42 & 311 & 0.769 & & & & \\
& 38.24 & 111 & 1.001 & $10.35 \pm 3.7$ & 4.0798 & \\
& 44.32 & 200 & 1.503 & & & & \\
& 64.67 & 220 & 0.687 & & & & \\
\hline
\end{tabular}

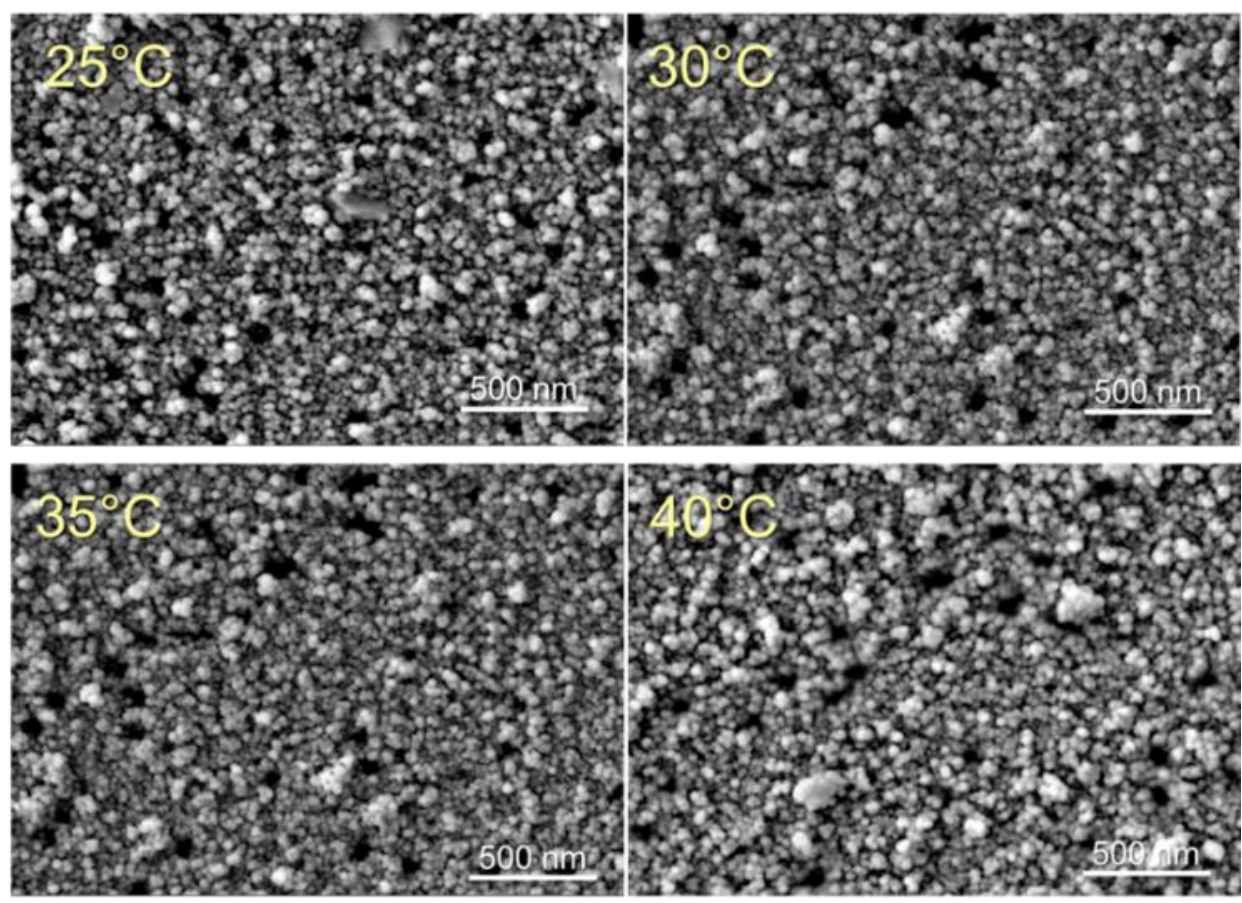

Figure 4. SEM images of Au-NTs/PET-ITMs catalysts after $1^{\text {st }}$ run at the different temperature 

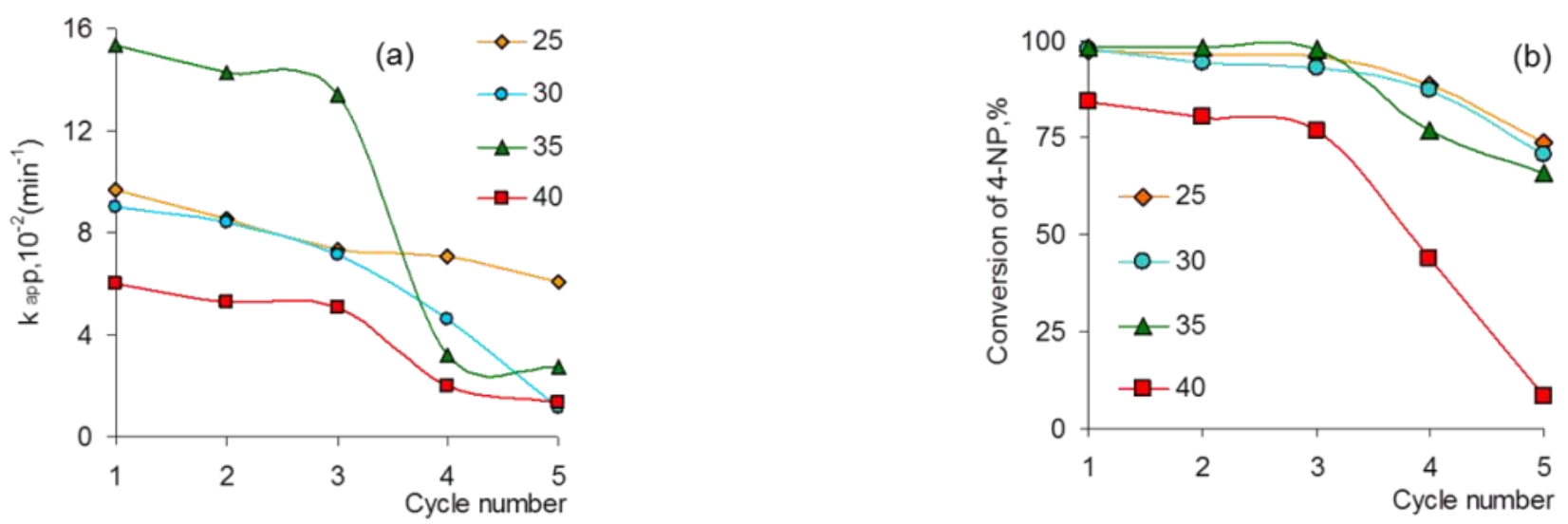

Figure 5. Changing of $k_{a p p}$ (a) and conversion of 4-NP for five reaction runs in presence of AuNTs/PET-ITMs composite in the temperature range of $25-40^{\circ} \mathrm{C}$

ture. The catalytic activities exhibited dramatically inverse relationship between $k_{a p p}$ and $T$ at the range from 35 to $40^{\circ} \mathrm{C}$. The possible reason was that the active sites of gold were removed from surface of composite during intensive stirring of the reaction media. The final effect on the morphology, size and aggregation of the gold nanoparticles was confirmed by XRD and SEM. The efficiency of the composite catalyst was unchanged in 3 runs and decreases by 24 $32 \%$ after the $5^{\text {th }}$ run (in temperature range of $25-35^{\circ} \mathrm{C}$ ). At the high temperature of $40{ }^{\circ} \mathrm{C}$ after the $5^{\text {th }}$ run the composite convert only $8 \%$ of 4 -NP and become completely catalytically inert.

\section{Acknowledgment}

This work was supported by the Ministry of Education and Science of the Republic of Kazakhstan under project AP05130797.

\section{References}

[1] Apel, P. (2001). Track Etching Technique in Membrane Technology. Radiation Measurements, 34(1-6): 559-566.

[2] Starosta, W. (2017). Radiation Use in Producing Track-Etched Membranes. In: Sun, Y. and Chmielewski, A.G. (eds). Applications of Ionizing Radiation in Materials Processing (32 p). Instytut Chemii i Techniki Jądrowej.

[3] Korolkov, I.V., Mashentseva, A.A., Güven, O., Zdorovets, M.V., Taltenov, A.A. (2015). Enhancing Hydrophilicity and Water Permeability of PET Track-Etched Membranes by Advanced Oxidation Process. Nuclear Instruments and Methods in Physics Research, Section B: Beam Interactions with Materials and Atoms, 365: 651-655.
[4] Barsbay, M., Güven, O. (2014). Grafting in Confined Spaces: Functionalization of $\mathrm{Na}$ nochannels of Track-Etched Membranes. Radiation Physics and Chemistry, 105: 26-30.

[5] Nguyen, Q.H., Ali, M., Nasir, S., Ensinger, W. (2015). Transport Properties of Track-Etched Membranes Having Variable Effective PoreLengths. Nanotechnology, 26(48): 485502.

[6] Kamakshi, Kumar, R., Saraswat, V.K., Kumar, M., Awasthi, K. (2017). Palladium Nanoparticle Binding in Functionalized Track Etched PET Membrane for Hydrogen Gas Separation. International Journal of Hydrogen Energy, 42(25): 16186-16194.

[7] Apel, P.Y., Blonskaya, I.V, Orelovitch, O.L., Sartowska, B.A., Spohr, R. (2012). Asymmetric Ion Track Nanopores for Sensor Technology. Reconstruction of Pore Profile from Conductometric Measurements. Nanotechnology, 23(22): 225503.

[8] Howorka, S., Siwy, Z.S. (2012). Nanopores as Protein Sensors. Nature Biotechnology, 30(6): 506-507.

[9] Muench, F., Sun, L., Kottakkat, T., Antoni, M., Schaefer, S., Kunz, U., Ensinger, W. (2017). Free-Standing Networks of Core-Shell Metal and Metal Oxide Nanotubes for Glucose Sensing. ACS Applied Materials \& Interfaces, 9(1): 771-781.

[10] Tunuguntla, R.H., Henley, R.Y., Yao, Y.-C., Pham, T.A., Wanunu, M., Noy, A. (2017). Enhanced Water Permeability and Tunable Ion Selectivity in Subnanometer Carbon Nanotube Porins. Science, 357(6353): 792-796.

[11] Yaroshchuk, A., Zhukova, O., Ulbricht, M., Ribitsch, V. (2005). Electrochemical and Other Transport Properties of Nanoporous TrackEtched Membranes Studied by the G Current Switch-off Technique. Langmuir, 21(15): 6872-6882. 
[12] Durney, A.R., Frenette, L.C., Hodvedt, E.C., Krauss, T.D., Mukaibo, H. (2016). Fabrication of Tapered Microtube Arrays and Their Application as a Microalgal Injection Platform. ACS Applied Materials and Interfaces, 8(50): 34198-34208.

[13] Kadyrzhanov, K.K., Kozlovskiy, A.L., Kanyukov, E.Y., Mashentseva, A.A., Zdorovets, M.V., Shumskaya, E.E. (2017). Variation of Polymer-Template Pore Geometry as a Means of Controlling the Magnetic Properties of Metallic Nanostructures. Petroleum Chemistry: 57(9), 790-795.

[14] Spain, E., McCooey, A., Joyce, K., Keyes, T.E., Forster, R.J. (2015). Gold Nanowires and Nanotubes for High Sensitivity Detection of Pathogen DNA. Sensors and Actuators B: Chemical, 215: 159-165.

[15] Kozlovskiy, A.L., Korolkov, I.V., Kalkabay, G., Ibragimova, M.A., Ibrayeva, A.D., Zdorovets, M.V., Kaniukov, E.Y. (2017). Comprehensive Study of Ni Nanotubes for Bioapplications: From Synthesis to Payloads Attaching. Journal of Nanomaterials, 2017: 1-9.

[16] Muench, F., Rauber, M., Stegmann, C., Lauterbach, S., Kunz, U., Kleebe, H.-J., Ensinger, W. (2011). Ligand-optimized Electroless Synthesis of Silver Nanotubes and their Activity in the Reduction of 4-Nitrophenol. Nanotechnology, 22(41): 415602.

[17] Mashentseva, A.A., Borgekov, D.B., Niyazova, D.T., Zdorovets, M.V. (2015). Evaluation of the Catalytic Activity of the Composite TrackEtched Membranes for P-Nitrophenol Reduction Reaction. Petroleum Chemistry, 55(10): 810-815.

[18] Muench, F., Kunz, U., Neetzel, C., Lauterbach, S., Kleebe, H.-J., Ensinger, W. (2011). 4(Dimethylamino)pyridine as a Powerful Auxiliary Reagent in the Electroless Synthesis of Gold Nanotubes. Langmuir, 27(1), 430435.

[19] Pozun, Z.D., Rodenbusch, S.E., Keller, E., Tran, K., Tang, W., Stevenson, K.J., Henkelman, G. (2013). A Systematic Investigation of p-Nitrophenol Reduction by Bimetallic Dendrimer Encapsulated Nanoparticles. Journal of Physical Chemistry C, 117(15): 7598-7604.

[20] Borgekov, D., Mashentseva, A., Kislitsin, S., Kozlovskiy, A., Russakova, A., Zdorovets, M. (2015). Temperature Dependent Catalytic Activity of Ag/PET ion-Track Membranes Composites. Acta Physica Polonica A, 128: 871874.

[21] Mashentseva, A., Borgekov, D., Zdorovets, M., Russakova, A. (2014). Synthesis, Structure, and Catalytic Activity of Au/Poly(Ethylene Terephthalate) Composites. Acta Physica Polonica A, 125: 1263-1266.
[22] Felix, E.-M., Antoni, M., Pause, I., Schaefer, S., Kunz, U., Weidler, N., Ensinger, W. (2016). Template-based Synthesis of Metallic Pd Nanotubes by Electroless Deposition and their Use as Catalysts in the 4-Nitrophenol Model Reaction. Green Chem., 18(2): 558-564.

[23] Mashentseva, A., Borgekov, D., Kislitsin, S., Zdorovets, M., Migunova, A. (2015). Comparative Catalytic Activity of PET Track-Etched Membranes with Embedded Silver and Gold Nanotubes. Nuclear Instruments and Methods in Physics Research, Section B: Beam Interactions with Materials and Atoms, 365: 7074 .

[24] Muench, F., Hussein, L., Stohr, T., Kunz, U., Ayata, S., Gärtner, I., Ensinger, W. (2016). Templated Synthesis of Pure and Bimetallic Gold/Platinum Nanotubes using Complementary Seeding and Plating Reactions. Colloids and Surfaces A: Physicochemical and Engineering Aspects, 508: 197-204.

[25] Schaefer, S., Felix, E.-M., Muench, F., Antoni, M., Lohaus, C., Brötz, J., Ensinger, W. (2016). NiCo Nanotubes Plated on Pd Seeds as a Designed Magnetically Recollectable Catalyst with High Noble Metal Utilization. RSC Advances, 6(74): 70033-70039.

[26] Muench, F., Bohn, S., Rauber, M., Seidl, T., Radetinac, A., Kunz, U., Ensinger, W. (2014). Polycarbonate Activation for Electroless Plating by Dimethylaminoborane Absorption and Subsequent Nanoparticle Deposition. Applied Physics A, 116(1): 287-294.

[27] Korolkov, I.V., Borgekov, D.B., Mashentseva, A.A., Güven, O., Atlcl, A.B., Kozlovskiy, A. L., Zdorovets, M. V. (2017). The Effect of Oxidation Pretreatment of Polymer Template on the Formation and Catalytic Activity of Au/PET Membrane Composites. Chemical Papers, 71(12): 2353-2358.

[28] Pradhan, N., Pal, A., Pal, T. (2001). Catalytic Reduction of Aromatic Nitro Compounds by Coinage Metal Nanoparticles. Langmuir, 17(5), 1800-1802.

[29] You, H., Fang, J. (2016). Particle-mediated Nucleation and Growth of SolutionSynthesized Metal Nanocrystals: A New Story Beyond the LaMer Curve. Nano Today, 11(2): 145-167.

[30] Xie, Z., Liu, Z., Wang, Y., Yang, Q., Xu, L., Ding, W. (2010). An Overview of Recent Development in Composite Catalysts from Porous Materials for Various Reactions and Processes. International Journal of Molecular Sciences, 11(5): 2152-2187. 